\title{
Publisher Correction: Cryo-EM structure of the sodium-driven chloride/bicarbonate exchanger NDCBE
}

Weiguang Wang, Kirill Tsirulnikov, Hristina R. Zhekova, Gülru Kayık, Hanif Muhammad Khan, Rustam Azimov, Natalia Abuladze, Liyo Kao, Debbie Newman, Sergei Yu. Noskov (D, Z. Hong Zhou (D), Alexander Pushkin \& Ira Kurtz

Correction to: Nature Communications https://doi.org/10.1038/s41467-021-25998-2, published online 28 September 2021.

The original version of this Article contained an error in the 'Methods' section, which incorrectly read ' $<\mathrm{Na}^{+}$-anctional anal 3 ' anctional analysist assays $>$ '. The correct version states ' $<\mathrm{Na}^{+}$-driven $\mathrm{Cl}^{-} / \mathrm{HCO}^{-}$exchange transport assays $>$' in place of ' $<\mathrm{Na}^{+}$-anctional anal3 ${ }^{-}$anctional analysist assays $>$'. This has been corrected in both the PDF and HTML versions of the Article.

Published online: 13 October 2021

\begin{abstract}
(c) (i) Open Access This article is licensed under a Creative Commons Attribution 4.0 International License, which permits use, sharing, adaptation, distribution and reproduction in any medium or format, as long as you give appropriate credit to the original author(s) and the source, provide a link to the Creative Commons license, and indicate if changes were made. The images or other third party material in this article are included in the article's Creative Commons license, unless indicated otherwise in a credit line to the material. If material is not included in the article's Creative Commons license and your intended use is not permitted by statutory regulation or exceeds the permitted use, you will need to obtain permission directly from the copyright holder. To view a copy of this license, visit http://creativecommons.org/licenses/by/4.0/.
\end{abstract}

(C) The Author(s) 2021 